\title{
Establishment and characterization of a cell line (NOMH-1) originating from a human endometrioid adenocarcinoma of the ovary
}

Takashi Yamada ${ }^{1 *}$, Takayoshi Kanda ${ }^{2}$, Hiroshi Mori ${ }^{3}$, Kaname Shimokawa ${ }^{1}$, Mitsuo Kagawa ${ }^{1}$ and Yuro Shibayama ${ }^{1}$

\begin{abstract}
Background: Cell lines are very useful for clinical and basic research. Thus far, only 11 reports have documented the characteristics of ovarian endometrioid adenocarcinoma cell lines in the literature. Due to the scarcity of information, the establishment of an ovarian malignant tumor cell line with distinctive characteristics is particularly important to study this disease. Thus, this study was undertaken to establish and characterize a new human endometrioid adenocarcinoma cell line of the ovary.

Methods: The cell line NOMH-1 was established from an ovarian tumor of a 44-year-old woman. Features of the cell line studied included morphology, chromosome analysis, heterotransplantation, tumor markers, and chemosensitivity.

Results: This cell line has been growing well for 232 months and subcultured more than 50 times. Monolayer cultured cells were polygonal in shape, showing a pavement-like arrangement and a tendency to stack without contact inhibition. They exhibited a human karyotype with a modal chromosomal number in the hypertriploid range. The cells could be transplanted into the subcutis of nude mice and produced tumors resembling the original tumor. NOMH-1 cells expressed both CEA and CA19-9 which were identified immunohistochemically in the original tumor and the heterotransplanted tumor. The cells were sensitive to paclitaxel, an agent commonly used in the treatment of gynecological cancers.

Conclusions: $\mathrm{NOMH}-1$ is the first ovarian endometrioid adenocarcinoma cell line in which CEA and CA19-9 expression have been defined. This newly established cell line should be useful for investigating the characteristics of ovarian endometrioid adenocarcinoma.
\end{abstract}

Keywords: Endometrioid adenocarcinoma, Ovary, Cell line, Chemosensitivity, MTT assay, Tumor marker

\section{Background}

Endometrioid adenocarcinoma of the ovary is a variant of epithelial ovarian cancer and has frequent concurrence with endometriotic lesions. Recent studies suggest that most endometrioid cancers arise from endometriosis $[1,2]$, and they are sometimes associated with carcinoma of the endometrium [3]. Therefore, it was considered important to develop an ovarian endometrioid adenocarcinoma cell line for clinical and basic research of this disease. We describe here the establishment

\footnotetext{
* Correspondence: yamatakashi@mub.biglobe.ne.jp

'Department of Pathology, Osaka Medical College, 2-7 Daigaku-machi,

Takatsuki, Osaka 569-8686, Japan

Full list of author information is available at the end of the article
}

and characterization of a new human cell line (NOMH-1) of ovarian endometrioid adenocarcinoma that express both carcinoembryonic antigen (CEA) and CA 19-9.

\section{Methods}

Patient and clinical background

On June 30, 1993, we performed an abdominal simple total hysterectomy, bilateral salpingo-oophorectomy, and omentectomy on a 44-year-old woman with ovarian cancer FIGO stage IIc (Figure 1). The patient gave informed consent for performance of this study. Histology was performed on the resected tissue, and the tumor was diagnosed as an endometrioid adenocarcinoma of the ovary by intraoperative diagnosis of frozen section.

\section{Biomed Central}



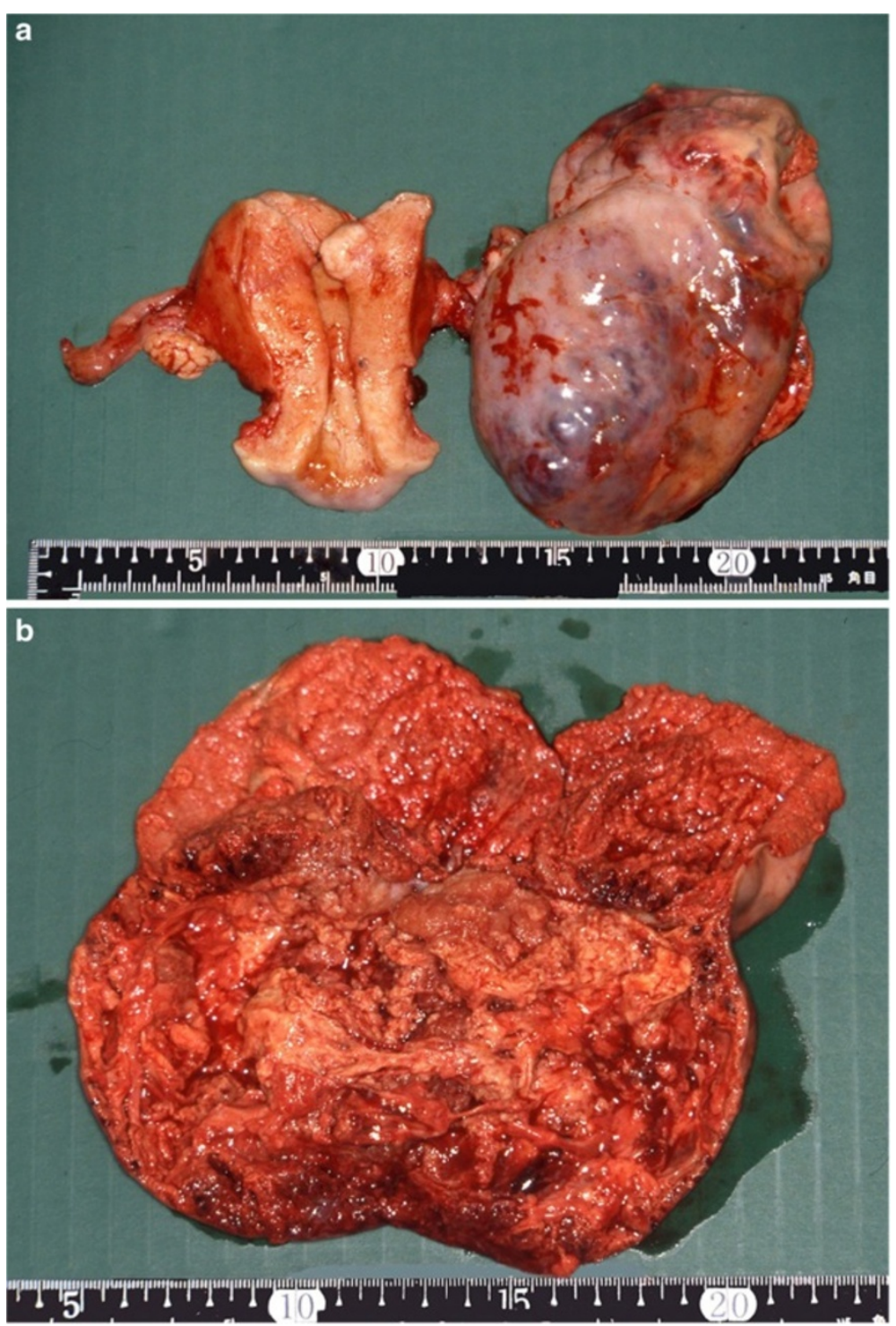

Figure 1 Macroscopic appearance of the original tumor $(a, b)$. The left ovary was a solid tumor.

Assessment of preoperative serum tumor marker levels showed that CA 125 was $639 \mathrm{U} / \mathrm{ml}$ (normal level $<35 \mathrm{U} / \mathrm{ml})$, CA 19-9 was $108 \mathrm{U} / \mathrm{ml}(<37 \mathrm{U} / \mathrm{ml})$, and CEA was $2.4 \mathrm{ng} / \mathrm{ml}(<2.5 \mathrm{ng} / \mathrm{ml})$. The patient was treated twice with $100 \mathrm{mg}$ cisplatin (CDDP) and $400 \mathrm{mg}$ etoposide (VP-16) intraperitoneally, and 5 times with $450 \mathrm{mg}$ carboplatin (CBDCA), $60 \mathrm{mg}$ pirarubicin hydrochloride (THP), and $400 \mathrm{mg}$ cyclophosphamide (CPA) intravenously. However, a follow up examination on March 25, 1994 showed that her serum tumor markers were increased: CA 125 was $158 \mathrm{U} / \mathrm{ml}$, CA 19-9 was $438 \mathrm{U} / \mathrm{ml}$, and CEA was $6.3 \mathrm{ng} / \mathrm{ml}$. Her clinical condition deteriorated progressively because of a recurrent abdominal tumor, and she died on October 11, 1994.

\section{Culture techniques and culture media}

Tissue from the resected ovarian tumor was finely minced with a pair of sharp blades in a dish including serum-free Ham's F-12 medium (Flow Laboratories Inc., McLean, VA), stirred slowly with a magnetic stirrer in a $0.25 \%$ trypsin solution (Flow Laboratories Inc.), centrifuged at $70 \mathrm{~g}$ for $5 \mathrm{~min}$, and placed in culture medium at $37^{\circ} \mathrm{C}$ in humidified $5 \% \mathrm{CO}_{2}$ and $95 \%$ air. Cells were cultured in Ham's F-12 medium plus 20\% precolostrum newborn calf serum (Mitsubishi Chemical Industries Ltd., Tokyo, Japan) with kanamycin. Then, subcultures were passaged with $0.1 \%$ trypsin and $0.02 \%$ ethylenediamine-tetraacetic acid (EDTA) solution every 4 weeks. Six months after the primary culture, 
the concentration of precolostrum newborn calf serum in the culture medium was reduced from $20 \%$ to $10 \%$.

\section{Morphology of the resected original tumor and cultured cells}

Living cells grown in culture flasks were examined using a phase contrast microscope. For histology, the original tumor was fixed in $10 \%$ formalin, embedded in paraffin, and $4 \mu \mathrm{m}$-sections were stained with hematoxylin-eosin (HE). Monolayer cells cultured on slides were fixed in 90\% ethanol and stained by Papanicolaou's procedure [4]. For electron microscopy, the original tumor was fixed by immersion in a mixture of $1.25 \%$ glutaraldehyde and $1 \%$ paraformaldehyde buffered with phosphate saline, $\mathrm{pH} 7.4$, at $4^{\circ} \mathrm{C}$ for $3 \mathrm{hr}$. After washing with phosphate buffered saline (PBS), the tumor was postfixed with $1 \%$ osmium tetroxide at $4^{\circ} \mathrm{C}$ for $1 \mathrm{hr}$, then washed in PBS, dehydrated in graded concentrations of ethanol, and embedded in Epon 812. Sections $0.5 \mu \mathrm{m}$ thick were cut with a 6000 ultramicrotome (Sorvall, Du Pont, CT) and stained with toluidine blue. Ultrathin sections exhibiting light gold interference color were cut from the corresponding areas in the toluidine blue stained sections, double stained with uranyl acetate and lead citrate, and observed under a JEM-100SX electron microscope (JEOL, Tokyo, Japan) at $80 \mathrm{kV}$ [5].

\section{Growth characteristics}

Cell characteristics were examined in passages 5-10. Suspensions of $1 \times 10^{5}$ cells were plated in $35 \mathrm{~mm}$ plastic dishes and incubated for 44 days. Then, cells from two dishes were counted every other day by an automatic cell counter (Coulter Counter ${ }^{\mathrm{R}}$, Coulter Electronics, Luton, England). The population doubling time and saturation density were calculated from the growth curve. For studies of plating efficiency, $1 \times 10^{2}$ and $2 \times 10^{2}$ single-suspension cells were placed into five $60 \mathrm{~mm}$ plastic dishes each and cultured for 21 days. Plating efficiency was determined by the ratio of the number of colonies (more than 10 cells) to the total number of inoculated cells. For the mitotic index, monolayer cells were cultured for 5 days and treated with $1 \times 10^{-7} \mathrm{M}$ colcemid (Demecolcine Solution, Wako Pure Chemical Industries, Osaka, Japan) for $4 \mathrm{hr}$, placed in a $0.2 \% \mathrm{KCl}$ solution for $15 \mathrm{~min}$, and then fixed step-by-step in a methanol: acetic acid solution (3:1). After air-drying, the cells were stained with Giemsa and the number of mitotic cells in 1,000 cells were counted.

\section{Chromosome analysis}

Histograms of chromosome number distribution were determined using 39 metaphase plates. Their karyotypes were analyzed in 10 cells in accordance with the International System for Human Cytogenetic Nomenclature (ISCN 1995).

\section{Heterotransplantation}

Ten million cells (passage 10) were inoculated subcutaneously into the dorsal region of 6 -week-old nude mice (BALB/cAJcl-nu; Clea Japan, Inc., Tokyo, Japan). When the tumors had grown to $5-10 \mathrm{~mm}$ in diameter after 4 weeks, they were removed and processed for morphological examinations. For histology, the excised tumors were fixed in $10 \%$ formalin, embedded in paraffin, and stained with HE. For electron microscopy, the tumors were cut into pieces with a pair of sharp blades fixed, stained, and observed as described above.

\section{Tumor markers}

Culture medium in which $2 \times 10^{6}$ cells / $5 \mathrm{ml}$ were cultured for 7 days was examined for $\alpha$ fetoprotein (AFP), CA 125, CA 19-9, CA 72-4, CEA, human chorionic gonadotropin (HCG), squamous cell carcinoma (SCC) antigen, and tissue polypeptide antigen (TPA) by radioimmunoassay or chemiluminescent immunoassay.

\section{Immunohistochemical stainings}

Deparaffinized sections of the original and heterotransplanted tumors on glass slides were immunohistochemically stained using the universal Immuno-enzyme Polymer (UIP) method (Envision kit; DAKO, Glostrup, Denmark). Slides were immersed in $0.03 \%$ hydrogen peroxidase and absolute methanol to block endogenous peroxidase, and then washed with phosphate buffered saline and heated in an autoclave for $20 \mathrm{~min}$. After cooling, the slides were incubated with a primary antibody at room temperature for $40 \mathrm{~min}$ and then reacted with Envision (DAKO) at room temperature for $30 \mathrm{~min}$, followed by incubation with diaminobenzidine (DAB) for 5-10 min. Antibodies against CA 125 (DAKO), CA 19-9 (DAKO), CEA (DAKO), and P53 (DAKO) were used to detect tumor markers, and against human estrogen receptor $\alpha$ (Nichirei Bioscience Inc., Tokyo, Japan) and human progesterone receptor (Nichirei) to detect hormone receptors.

\section{Chemosensitivity assays}

The effects of actinomycin D (ACD, MSD KK, Tokyo, Japan), doxorubicin (ADM, Kyowa Hakko Kirin Co., Ltd., Tokyo, Japan), 5-fluorouracil (5-FU, Kyowa Hakko Kirin Co.), mitomycin C (MMC, Kyowa Hakko Kirin Co.), bleomycin (BLM, Nippon Kayaku Co., Ltd., Tokyo, Japan), vinblastine (VLB, Nippon Kayaku Co.), vincristine (VCR, Nippon Kayaku Co.), carboplatin (CBDCA, Bristol-Myers K.K., Tokyo, Japan), cisplatin (CDDP, BristolMyers), etoposide (VP-16, Bristol-Myers), paclitaxel (PTX, 

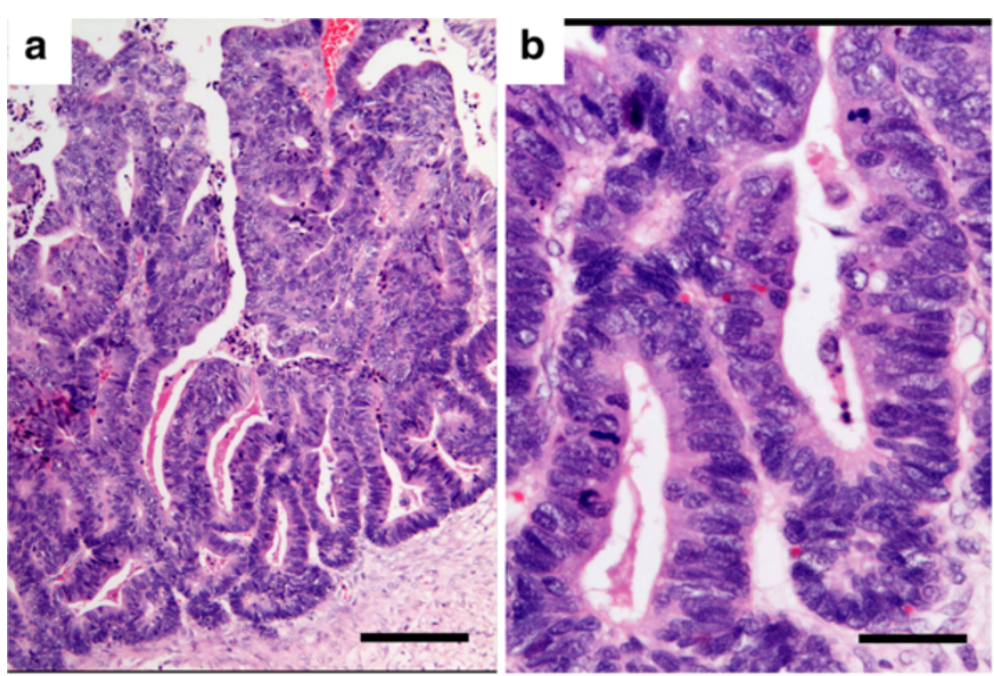

Figure 2 Histology of the original tumor. It shows an endometrioid adenocarcinoma stained with hematoxylin and eosin (HE) (a,bar $=200 \mu \mathrm{m} ; \mathrm{b}, \mathrm{bar}=50 \mu \mathrm{m})$.

Bristol-Myers) [6], 4-hydroperoxy-cyclophosphamide (CPA, Shionogi \& Co., Ltd., Osaka, Japan), irinotecan SN-38 (CPT-11, Yakult Honsha Co., Ltd., Tokyo, Japan) [7], and methotrexate (MTX, Pfizer Japan Inc., Tokyo, Japan), which are often used to treat gynecological cancers [8], on the cultured cells were investigated by 3-(4,5-dimethyl-2thiazolyl)-2,5-diphenyl-2H tetrazolium bromide (MTT) assay. The drugs were dissolved in culture medium and used immediately. For MTT assay, $5 \times 10^{3}$ cells in $100 \mu \mathrm{l}$ medium were seeded in tetraplicate into each well of 96well microwell plates. For continuous drug exposure experiments, various diluted drugs in $50 \mu \mathrm{l}$ were added after $48 \mathrm{hr}$ of incubation. The wells were incubated for $72 \mathrm{hr}$ after the addition of drugs. MTT ( $50 \mu \mathrm{l}$ of $2 \mathrm{mg} / \mathrm{ml}$; Wako Pure Chemical Industries, Ltd, Osaka, Japan) was added to each well, and the plates were incubated for $4 \mathrm{hr}$.

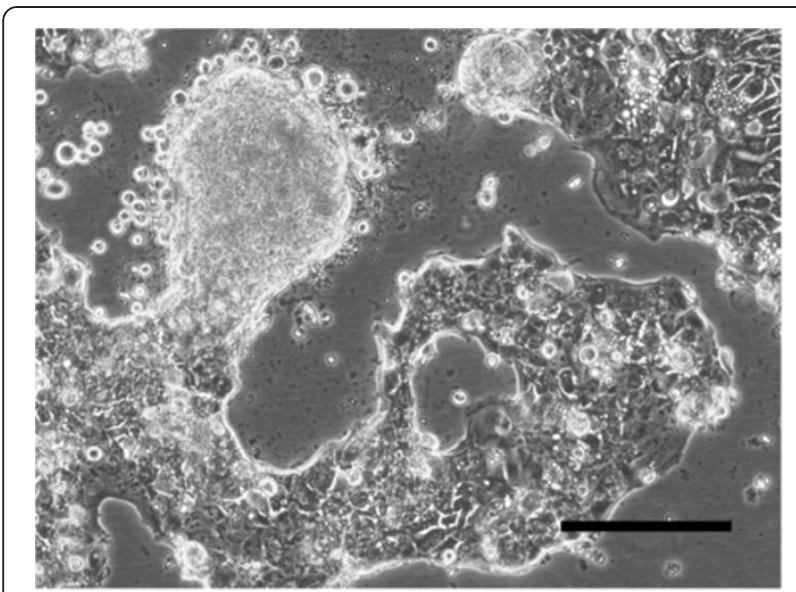

Figure 3 Phase contrast microscopy. The cells show a pavementlike arrangement and colonies with multilayering. (bar = $200 \mu \mathrm{m})$.
The medium was then removed, $150 \mu \mathrm{l}$ of dimethyl sulfoxide (DMSO, Sigma, St. Louis, MO) was added to each well, and the plates were agitated for $5 \mathrm{~min}$. The optical density was then read at $570 \mathrm{~nm}$ on a microplate reader (Bio-Rad Laboratories, Hercules, CA) and the effective concentration of the median lethal dose was calculated from the dose response curve (EC50: dose of drug required to reduce final cell number or optical density in MTT assay to $50 \%$ of control) [9].

\section{Results}

\section{Histopathology of the original tumor specimen}

Light microscopy revealed the original tumor to be an endometrioid adenocarcinoma, which showed tubular glands lined by stratified non-mucin containing epithelium (Figure 2).

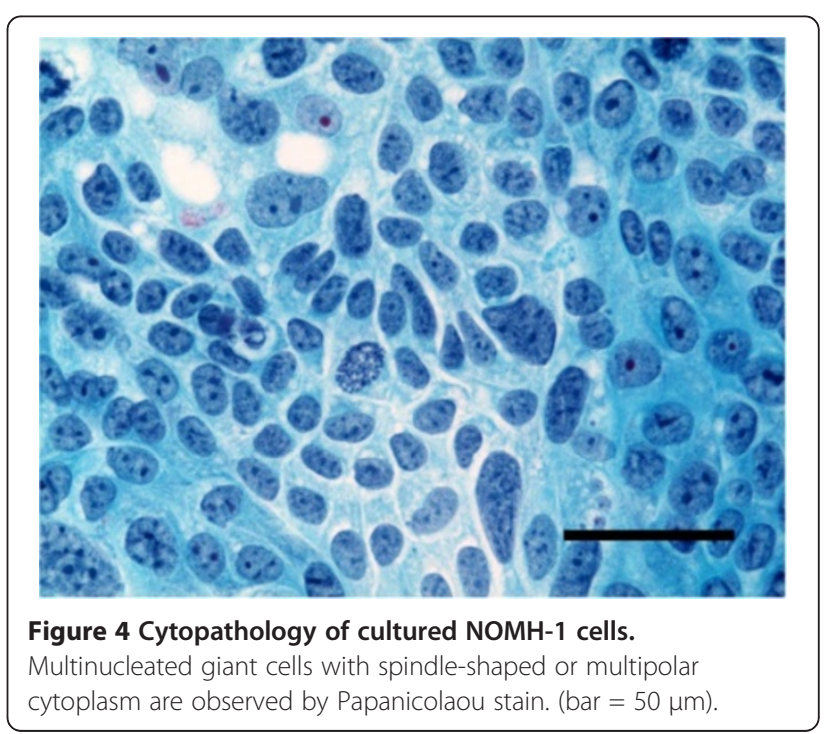



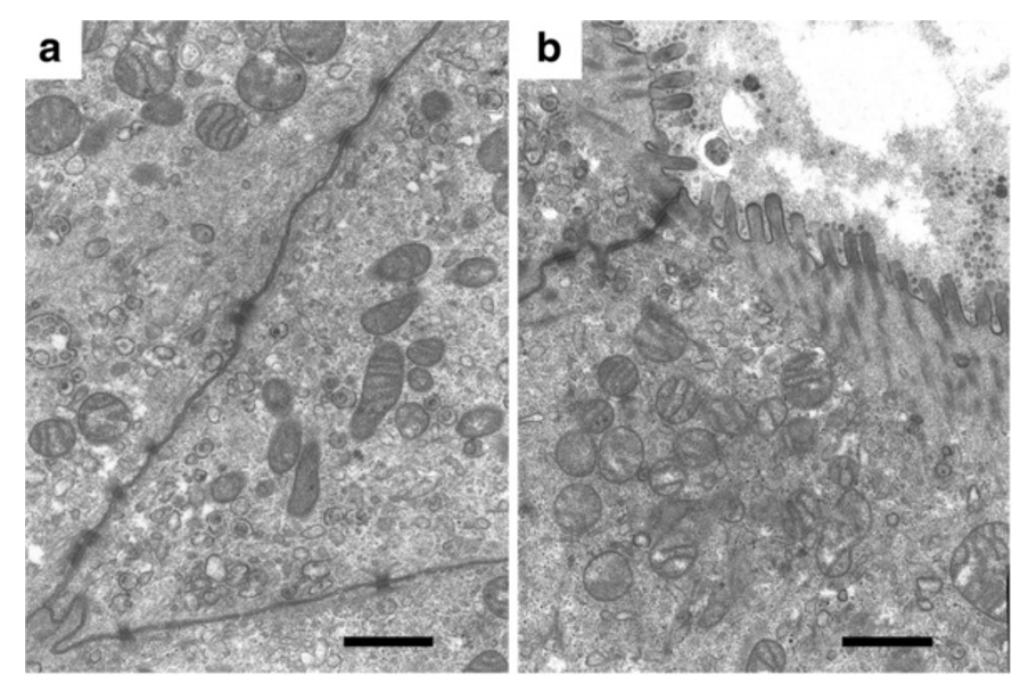

Figure 5 Electron micrograph of the original tumor. The cells are attached by desmosome-like junctions (a) and have abundant mitochondria in the cytoplasm (a)(b) and numerous microvilli on the surface (b). (a,b, bar $=1 \mu \mathrm{m})$.

\section{Establishment of the cell line}

Tissue fragments from the original tumor were cultured and after a 2-month stationary period, definite out-growths developed. Initially, contamination by spindle-shaped fibroblasts was observed, but they disappeared from the cultures upon passaging the cells, which were named NOMH-1. The NOMH-1 cells grew well, without interruption, for more than 232 months, and more than 50 serial passages were successively carried out. They continue to exhibit stable growth.

\section{Morphology of the cultured cells}

The cultured cells grew in monolayer and appeared to be epithelial, showing a pavement-like arrangement. Multilayering of cells was easily observed even before they reached confluency (Figure 3). The cells were polygonal and showed neoplastic features such as bizarre aggregation of chromatin granules, thickened nuclear membrane, and multiple large nucleoli. Multinucleated giant cells were also seen (Figure 4). Electron microscopy revealed that adjacent cells showed desmosomelike junctions (Figure 5a). The cells had indented nuclei

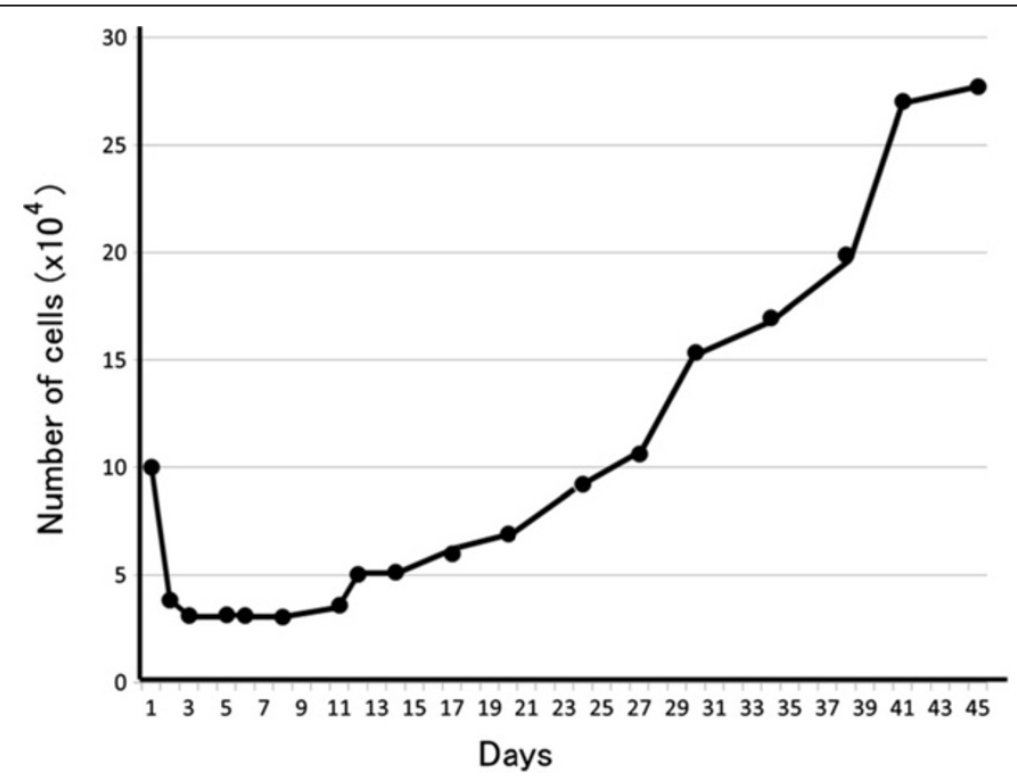

Figure 6 Growth curve of NOMH-1. The cells grew logarithmically. 


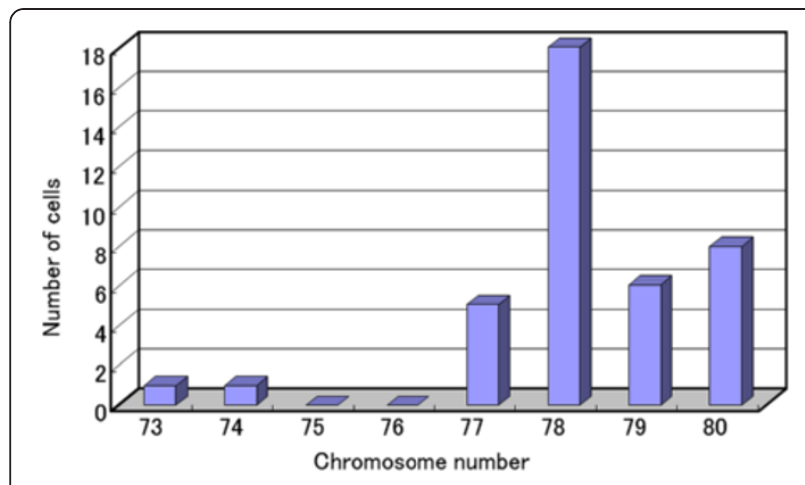

Figure 7 Distribution of chromosomal numbers in NOMH-1 (5th generation). The modal number is in the hypertriploid range.

(figure not shown), abundant mitochondria in the cytoplasm, and numerous microvilli on the cell surface (Figure 5b). These features suggested that the cells were epithelial in origin.

\section{Growth characteristics}

The growth curve was examined in passage 5 of the NOMH-1 cell line. Three days after culturing, the cells grew logarithmically (Figure 6). The population doubling time, saturation density, plating efficiency, and mitotic index were $273 \mathrm{hr}, 3.7 \times 10^{4}$ cells $/ \mathrm{cm}^{2}, 3.6 \%$, and $4.9 \%$, respectively.

\section{Chromosome analysis}

This cell line had a modal chromosome number that was in the hypertriploid range (73-80) (Figure 7).

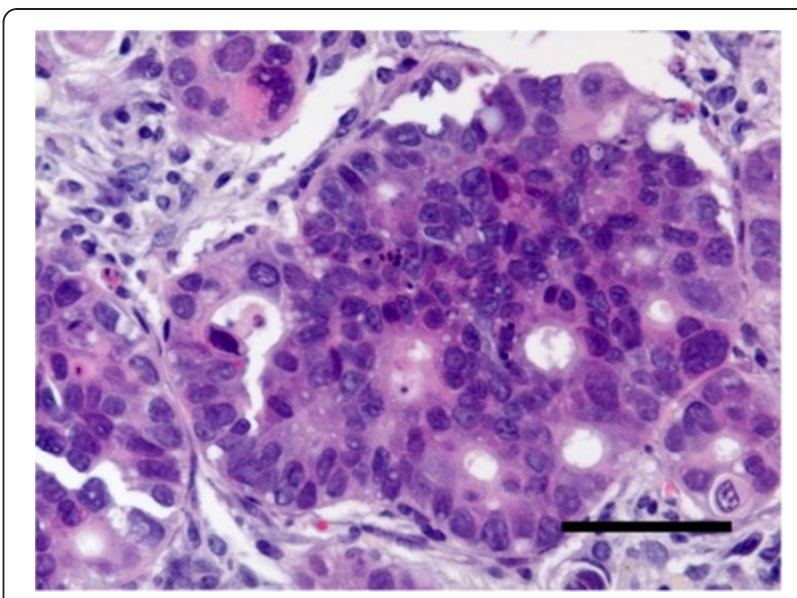

Figure 9 Micrograph of a tumor transplanted into a nude mouse. It shows endometrioid adenocarcinoma closely resembling the original tumor. ( $H E$, bar $=50 \mu \mathrm{m})$.

Chromosomal analysis showed that all of the cells had $6 q-$ and most of the cells had 8p+ (Figure 8).

\section{Heterotransplantation}

Histopathologically, the transplanted tumors were endometrioid adenocarcinomas that showed tubular glands lined by stratified non-mucin containing epithelium, which closely resembled the original tumor (Figure 9). Electron microscopy showed desmosome-like junctions and numerous microvilli as observed in the original tumor.

\section{Tumor markers}

This cell line was positive for the following tumor markers: CEA, 1,000 ng/ml; CA 19-9, $305 \mathrm{U} / \mathrm{ml}$; CA 72-4,

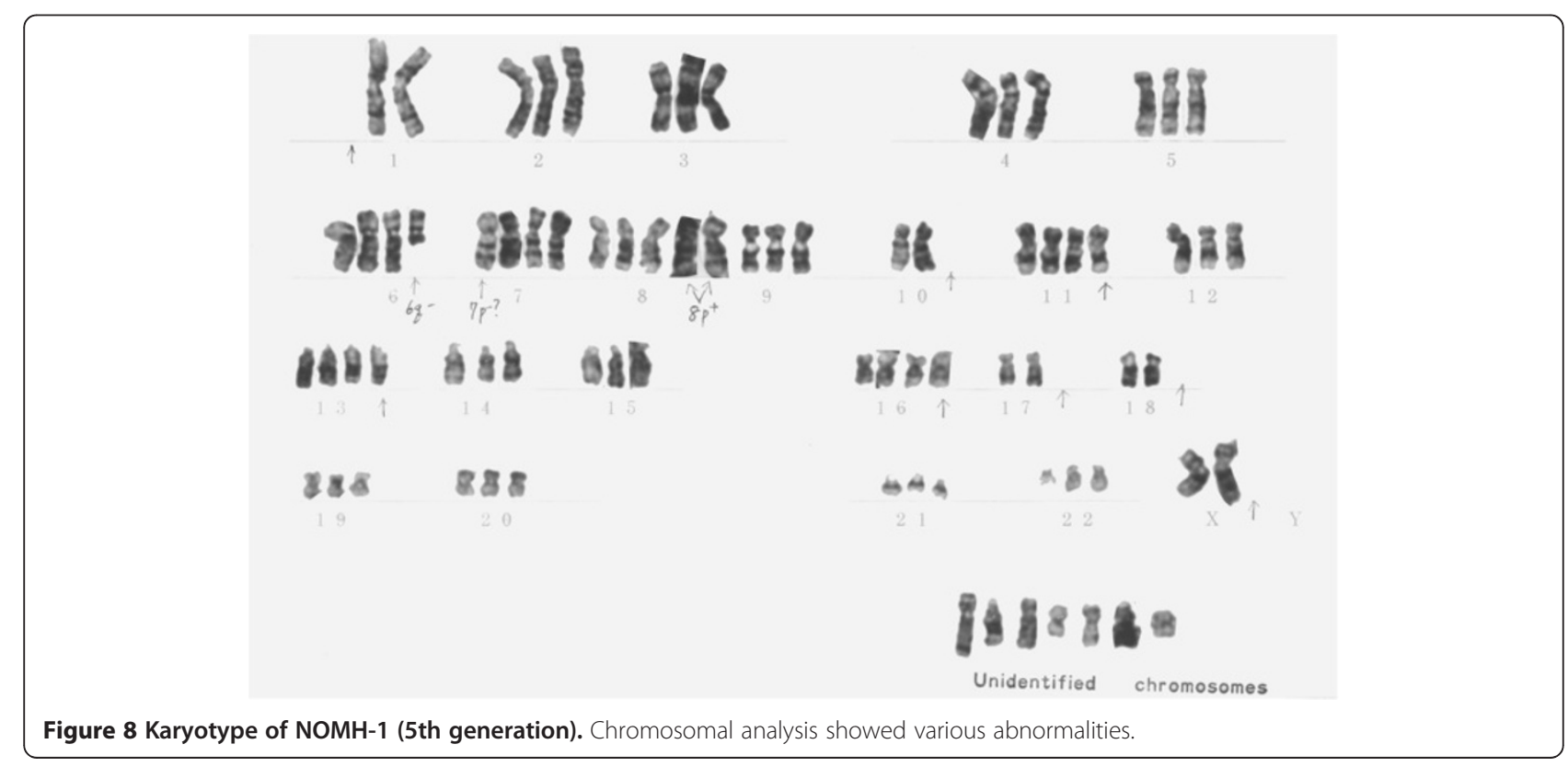



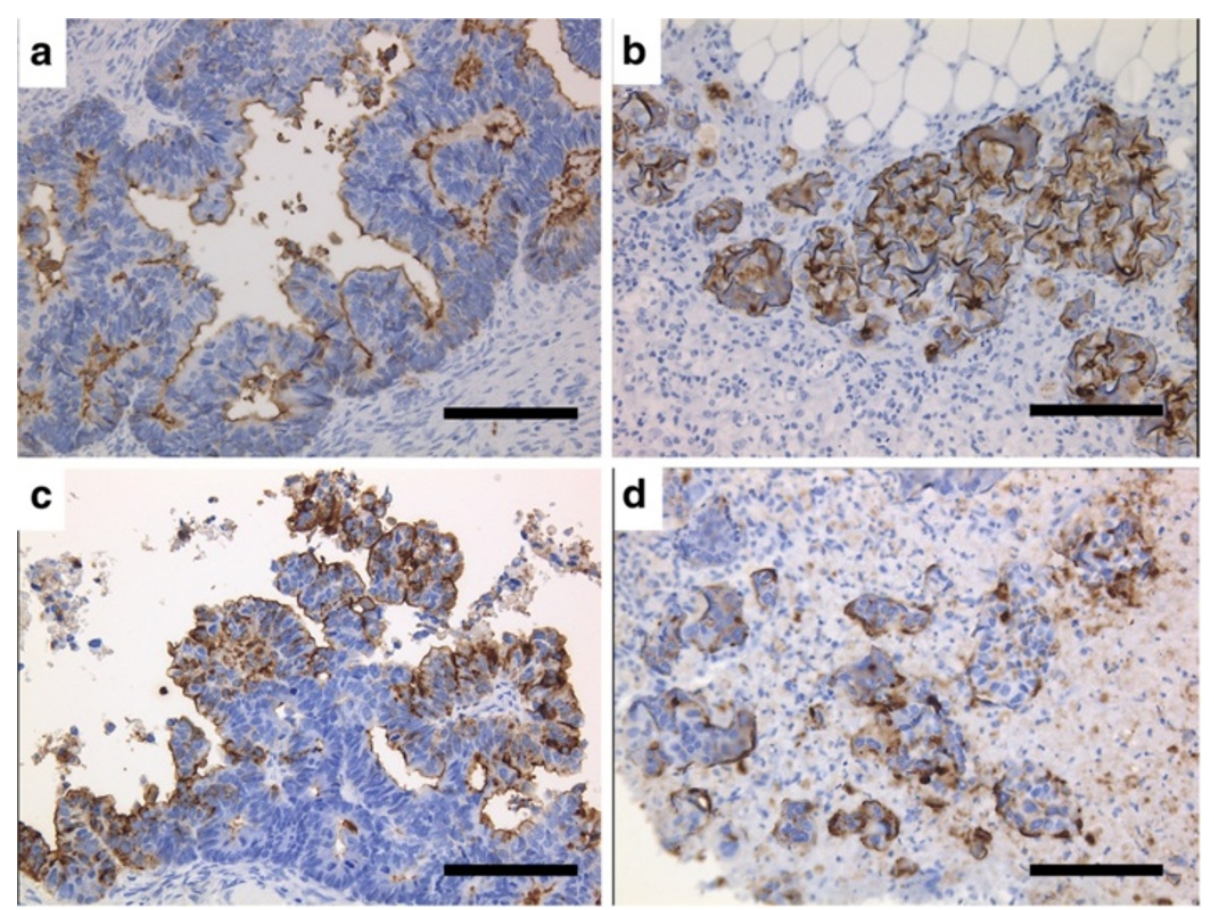

Figure 10 Immunohistochemical stainings of the original tumor $(a, c)$ and heterotransplanted tumor $(b, d)$ with CEA (a, b) and CA19-9 (c, d). (a, b, c, d; bar = $100 \mu \mathrm{m})$.

$5.0 \mathrm{U} / \mathrm{ml}$; and TPA, >1,500 U/L. On the other hand, they were negative for: AFP, $<1 \mathrm{ng} / \mathrm{ml}$; CA 125, $20 \mathrm{U} / \mathrm{ml}$; $\mathrm{HCG},<1 \mathrm{mIU} / \mathrm{ml}$; and SCC antigen, $<0.5 \mathrm{ng} / \mathrm{ml}$. Expression of CEA and CA 19-9 was demonstrated immunohistochemically in the cancer cells of the original and heterotransplanted tumors (Figure 10). In contrast, CA125 and P53 were negative immunohistochemically.

\section{Hormone receptors}

Neither estrogen receptor (ER) nor progesterone receptor $(\mathrm{PgR})$ were detected immunohistochemically in the original and heterotransplanted tumors.

\section{Chemosensitivity}

The EC50 values of anti-cancer drugs for NOMH-1 cells are listed in Table 1 (Figure 11).

\section{Discussion}

In this study, we established a novel cell line, NOMH-1, of human endometrioid adenocarcinoma of the ovary by culturing tissue fragments from a resected tumor, and to obtain convincing evidence that this cell line truly reflects the original tumor and disease, we investigated its biological characteristics. We found that these cells showed the following features: 1) viable in culture for over 232 months; 2) neoplastic, pleomorphic, and stack
Table 1 Chemosensitivity using a 3-(4,5-dimethylthiazol2-yl)-2,5-diphenyl tetrazolium bromide assay

\begin{tabular}{lll}
\hline Drug & $\begin{array}{l}\text { EC50 } \\
(\boldsymbol{\mu} \mathbf{g} / \mathbf{m L})\end{array}$ & $\begin{array}{l}\text { PPC } \\
(\boldsymbol{\mu g} / \mathbf{m L})\end{array}$ \\
\hline ACD & $>0.1$ & 0.08 \\
ADM & 16.5 & 0.4 \\
BLM & $>1000$ & 3.3 \\
CBDCA & $>300$ & 37.1 \\
CDDP & 23.2 & 8.5 \\
CPA & $>10$ & 4.3 \\
CPT-11 & 1.79 & 0.05 \\
5-FU & 497 & 15.3 \\
MMC & 6.5 & 2.4 \\
MTX & $>300$ & 3 \\
PTX & 5.1 & 11.8 \\
VCR & 15 & 0.1 \\
VLB & 16 & 0.15 \\
VP-16 & 197 & 13 \\
\hline
\end{tabular}

EC50, effective concentration for 50\% kill; PPC, peak plasma concentration taken intravenously; $A C D$, actinomycin $D$; ADM, doxorubicin; BLM, bleomycin; CBDCA, carboplatin; CDDP, cisplatin; CPA, 4-hydroperoxy-cyclophosphamide; CPT-11, irinotecan hydrochloride; 5-FU, 5-fluorouracil; MMC, mitomycin C; MTX, methotrexate; PTX, paclitaxel; VCR, vincristine; VLB, vinblastine; VP-16, etoposide; 


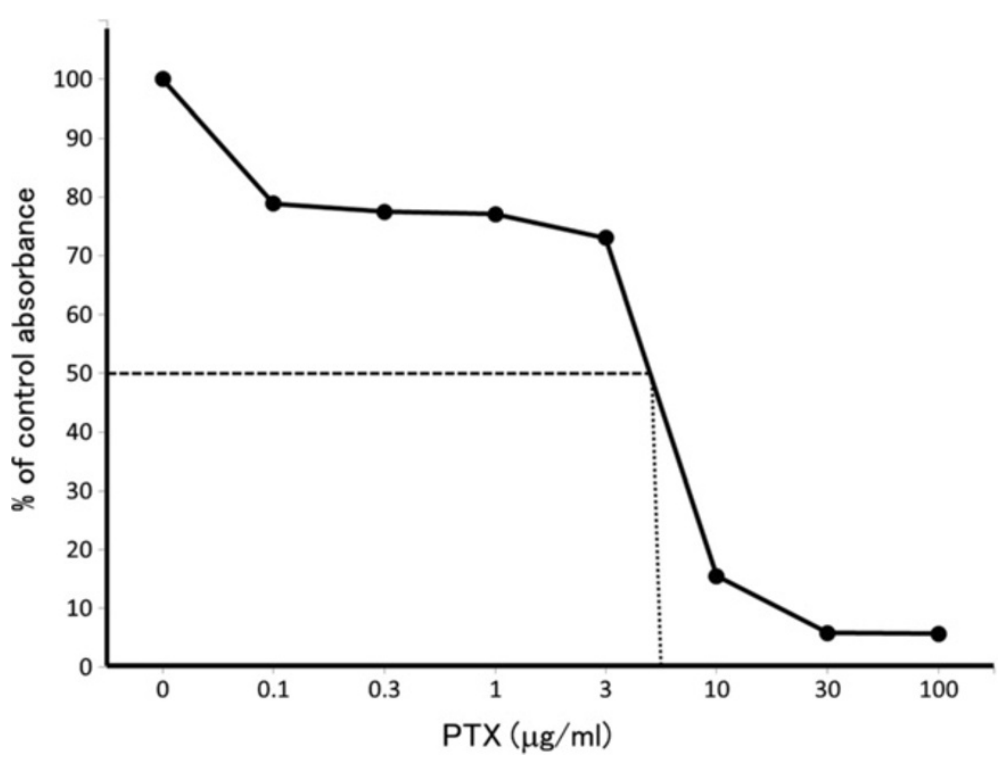

Figure 11 Dose response curve for paclitaxel. The EC50 value of paclitaxel is 5.1.

easily without contact inhibition; 3) chromosomes were of a human karyotype with aneuploid distribution; and 4) transplantable into nude mice and formed tumors which histologically resembled the original tumor.

Despite the advances in culturing technology, it is still difficult to establish a cell line, chiefly because of contamination by fibroblasts, which usually grow faster than epithelial cells and promote their detachment from the plate. To overcome this, we took advantage of the fact that fibroblasts detach faster than epithelial cells by trypsin, and we removed every fibroblast and most epithelial cells, leaving only a few colonies of epithelial cells to grow. The cells gradually grew well to form obvious colonies, and the first subculture was made 4 months after the primary culture.

Some ovarian endometrioid adenocarcinoma cell lines have been used for basic research, but only eleven of them (including \#2774 [10], endometrioid carcinoma cell

Table 2 Cell lines from ovarian endometrioid adenocarcinoma

\begin{tabular}{|c|c|c|c|c|c|c|c|}
\hline Cell line & Age & Materials & $\begin{array}{l}\text { Chromosome } \\
\text { Number }\end{array}$ & DT & Transplantability & Immunotaining & Characteristics \\
\hline \#2774 (1978) & - & ascites & $66-68$ & - & Yes & - & - \\
\hline - (1983) & 47 & ascites & $103(51-402)$ & 74.4 & Yes & - & - \\
\hline OVK18 (1983) & 49 & ascites & 47 (mode) & 48 & Yes & - & $\mathrm{ER}(-), \operatorname{PgR}(-)$ \\
\hline HMOA (1986) & 57 & ovarian tumor & 46-47 (mode) & $\begin{array}{l}72, \\
58\end{array}$ & Yes & - & production of CA125 \\
\hline HNOA (1986) & 71 & $\begin{array}{l}\text { transplanted } \\
\text { tumor }\end{array}$ & 46-47 (mode) & $\begin{array}{l}28 \\
24\end{array}$ & Yes & - & CA125(-) \\
\hline HOC-I (1989) & 40 & $\begin{array}{l}\text { recurrent } \\
\text { tumor }\end{array}$ & $46(44-49)$ & 75 & Yes & $\mathrm{ER}(-)$ & ER(-), production of CA125, TPA \\
\hline COV362 (1993) & - & - & $69(67-73)$ & - & - & - & - \\
\hline SIB-1 (1994) & 39 & $\begin{array}{l}\text { pleural } \\
\text { effusion }\end{array}$ & $46(43-54)$ & - & - & HMFG-2, CA125 & serum free medium \\
\hline SNU-251 (1997) & 47 & ascites & - & 46 & - & - & $\begin{array}{l}\text { CA125(-), CEA(-), p53, BRCA1, hMLH1 } \\
\text { mutation(+) }\end{array}$ \\
\hline SNU-563 (1997) & 54 & ovarian tumor & - & 67 & - & - & p53 mutation(+) \\
\hline NOE (2007) & 46 & tumor fluid & $65-74$ & - & Yes & - & $\mathrm{ER}(+)$ \\
\hline $\mathrm{NOMH}-1$ & 44 & ovarian tumor & $73-80$ & 273 & Yes & $\begin{array}{l}\text { CA19-9, CEA, ER(-), } \\
\operatorname{PgR}(-)\end{array}$ & production of CA19-9, CEA, TPA \\
\hline
\end{tabular}


line [11], OVK18 [12], HMOA [13], HNOA [13], HOC-I [14], COV362 [15], SIB-1 [16], SNU-251 [17], SNU-563 [17], and NOE [18] ) have had their characteristics described in detail in the literature (Table 2). Each cell line originated from an original tumor, recurrent tumor, ascites, pleural effusion, or tumor fluid. It seemed that cancer cells in the fluid were more easily cultured. The population doubling time varied greatly $(28-75 \mathrm{hr})$, the modal chromosome numbers were in the diploid range or more, and all the cells showed karyological abnormalities. Our NOMH-1 cells grew well and detached easily after multilayering, therefore, its population doubling time seemed longer than other cell lines.

While two previously reported cell lines were shown to produce CA125, only one was demonstrated immunohistologically. Tumor markers are useful not only in diagnosing ovarian cancer but also in detecting tumor recurrence or assessing therapy. In this patient, CEA and CA19-9 were especially useful tumor markers because her serum levels were postoperatively high, which were reproduced in the cultured cells. NOMH-1 is the first cell line of ovarian endometrioid adenocarcinoma which produces both CEA and CA 19-9. Therefore, it represents a good model for the study of ovarian cancers that express tumor markers.

The ovary is considered a target organ of steroid hormones, and while NOE expresses estrogen receptor, OVK18, HOC-I, and NOMH-1 produce neither estrogen receptor nor progesterone receptor. As the mechanism of action and localization of steroid hormone receptors are still largely unknown, NOMH-1 can be used as a non-hormone receptor cell line for studies on receptors.

Chemotherapy as well as surgery are very important modalities for the treatment of ovarian cancer. The CAP (CPA, ADM, CDDP) regimen had been commonly used for treatment of ovarian epithelial carcinoma, however, PTX and CBDCA have been recently used although they are not always effective. Thus, CPT-11 has been used for platinum- and taxanes-resistant epithelial ovarian cancer [19]. In order to determine the effects of chemotherapeutic reagents on NOMH-1 cells, chemosensitivity to a panel of drugs was measured using the MTT assay, which is still considered a rapid and accurate method of screening for drug responsiveness of cultured cells. In vitro sensitivity was defined as more than $50 \%$ growth inhibition at peak plasma concentrations. According to this criterion, we demonstrated that NOMH-1 cells were sensitive to PTX only. Unfortunately, PTX could not be used to treat the patient at that time, which reflected her severe clinical course.

Since it is impossible to establish a cell line from the malignant tumor of each patient, the cell line that we established and characterized would be very useful in basic research on ovarian cancer, especially endometrioid adenocarcinoma, the pathogenesis of which is not yet completely known.

\section{Abbreviations}

CEA: Carcinoembryonic antigen; CDDP: Cisplatin; VP-16: Etoposide; CBDCA: Carboplatin; THP: Pirarubicin hydrochloride; CBA: Cyclophosphamide; EDTA: Ethylenediamine-tetraacetic acid; HE: Hematoxylin-eosin; PBS: Phosphate buffered saline; ISCN: International System for Human Cytogenetic Nomenclature; AFP: a-feto-protein; HCG: Human chorionic gonadotropin; SCC: Squamous cell carcinoma; TPA: Tissue polypeptide antigen; UIP: Universal Immuno-enzyme Polymer; DAB: Diaminobenzidine; ACD: Actinomycin D; ADM: Doxorubicin; 5-FU: 5-fluorouracil; MMC: Mitomycin C; BLM: Bleomycin; VLB: Vinblastine; VCR: Vincristine; PTX: Paclitaxel; CPT-11: Irinotecan SN-38; MTX: Methotrexate; MTT: 3-(4,5dimethyl-2-thiazolyl)-2,5-diphenyl-2H tetrazolium bromide; DMSO: Dimethyl sulfoxide; EC50: Effective concentration for 50\% kill.

\section{Competing interest}

The authors declare that they have no competing interests.

\section{Authors' contributions}

TY and TK carried out surgery of the patient and drafted the manuscript. KS and MK examined microscopically surgical specimen and performed the immunohistochemical staining of the tumor. HM and YS contributed to the final data analysis and drafted the manuscript. All authors read and approved the final manuscript.

\section{Author details}

'Department of Pathology, Osaka Medical College, 2-7 Daigaku-machi, Takatsuki, Osaka 569-8686, Japan. ${ }^{2}$ Department of Obstetrics and Gynecology, Osaka Minami Medical Center, 2-1 Kidohigashi-machi, Kawachinagano, Osaka 586-8521, Japan. ${ }^{3}$ Department of Clinical Pathology, Minoh City Hospital, 5-7-1 Kayano, Minoh, Osaka 562-8562, Japan.

Received: 4 January 2013 Accepted: 31 January 2013

Published: 4 February 2013

\section{References}

1. Jiang $X$, Hitchcock A, Bryan EJ, Watson RH, Englefield P, Thomas EJ, Campbell IG: Microsatellite analysis of endometriosis reveals loss of heterozygosity at candidate ovarian tumor suppressor gene loci. Cancer Res 1996, 56:3534-3539.

2. Sato N, Tsunoda H, Nishida M, Morishita Y, Takimoto Y, Kubo T, Noguchi M: Loss of heterozygosity on 10q23.3 and mutation of the tumor suppressor gene PTEN in benign endometrial cyst of the ovary: possible sequence progression from benign endometrial cyst to endometrioid carcinoma and clear cell carcinoma of the ovary. Cancer Res 2000, 60:7052-7056.

3. Soliman PT, Slomovitz BM, Broaddus RR, Sun CC, Oh JC, Eifel PJ, Gershenson DM, Lu KH: Synchronous primary cancers of the endometrium and ovary: a single institution review of 84 cases. Gynecol Oncol 2004, 94:456-462.

4. Papanicolaou GN: A new procedure for staining vaginal smears. Science 1942, 95:438-439

5. Masuda H, Fujihira S, Ueno H, Kagawa M, Katsuoka Y, Mori H: Ultrastructural study on cytotoxic effects of cyclosporine A in spermiogenesis in rats. Med Electron Microsc 2003, 36:183-191.

6. Tamura T, Sasaki Y, Nishiwaki Y, Saijo N: Phase I study of paclitaxel by three-hour infusion: hypotension just after infusion is one of the major dose-limiting toxicities. Jpn J Cancer Res 1995, 86:1203-1209.

7. Taguchi T, Wakui A, Hasegawa K, Niitani H, Furue H, Ohta K, Hattori T: Phase I clinical study of CPT-11. Research group of CPT-11. Gan To Kagaku Ryoho 1990, 17:115-120.

8. Yamada T, Ueda M, Otsuki Y, Ueki M, Sugimoto O: Establishment and characterization of a cell line (OMC-3) originating from a human mucinous cystadenocarcinoma of the ovary. Gynecol Oncol 1991, 40:118-128.

9. Twentyman PR, Luscombe M: A study of some variables in a tetrazolium dye (MTT) based assay for cell growth and chemosensitivity. $\mathrm{Br} J$ Cancer 1987, 56:279-285.

10. Freedman RS, Pihl E, Kusyk C, Gallager HS, Rutledge F: Characterization of an ovarian carcinoma cell line. Cancer 1978, 42:2352-2359. 
11. Nagai S, Nozawa S, Kurihara S, Mukai M: Cytologic and biologic studies of endometrioid carcinoma of the ovary. Acta Cytol 1983, 27:676-682.

12. Uehara S, Soh K, Hoshiai H, Yajima A, Suzuki M, Abe H: Establishment and characterization of human ovarian endometrioid carcinoma cell line. Nihon Sanka Fujinka Gakkai Zasshi 1983, 35:19-26.

13. Ishiwata I, Ishiwata C, Soma M, Ishikawa H: Establishment and characterization of two human ovarian endometrioid carcinoma cell lines (with or without squamous cell component). Gynecol Oncol 1986, 25:95-107.

14. Fujii T: Establishment and characterization of human ovarian endometrioid carcinoma cell line. Nihon Sanka Fujinka Gakkai Zasshi 1989, 41:161-166.

15. van den Berg-Bakker CA, Hagemeijer A, Franken-Postma EM, Smit VT, Kuppen PJ, van Ravenswaay Claasen HH, Cornelisse CJ, Schrier PI: Establishment and characterization of 7 ovarian carcinoma cell lines and one granulosa tumor cell line: growth features and cytogenetics. Int $J$ Cancer 1993, 53:613-620

16. Hirte HW, Kaiser JS, Bacchetti S: Establishment and characterization of four human epithelial ovarian carcinoma cell lines. Cancer 1994, 74:900-906.

17. Yuan Y, Kim WH, Han HS, Lee JH, Park HS, Chung JK, Kang SB, Park JG: Establishment and characterization of human ovarian carcinoma cell lines. Gynecol Oncol 1997, 66:378-387.

18. Umezu T, Kajiyama H, Terauchi M, Shibata K, Ino K, Nawa A, Kikkawa F: Establishment of a new cell line of endometrioid carcinoma of the ovary and its chemosensitivity. Hum Cell 2007, 20:71-76.

19. Matsumoto K, Katsumata N, Yamanaka Y, Yonemori K, Kohno T, Shimizu C, Andoh M, Fujiwara Y: The safety and efficacy of the weekly dosing of irinotecan for platinum- and taxanes-resistant epithelial ovarian cancer. Gynecol Oncol 2006, 100:412-416.

doi:10.1186/1757-2215-6-8

Cite this article as: Yamada et al:: Establishment and characterization of a cell line (NOMH-1) originating from a human endometrioid

adenocarcinoma of the ovary. Journal of Ovarian Research 2013 6:8.

\section{Submit your next manuscript to BioMed Central and take full advantage of:}

- Convenient online submission

- Thorough peer review

- No space constraints or color figure charges

- Immediate publication on acceptance

- Inclusion in PubMed, CAS, Scopus and Google Scholar

- Research which is freely available for redistribution 